\title{
CONTRIBUŢII LA STUDIUL ORTOPTEROFAUNEI (ORTHOPTERA) DIN MUNICIPIUL CHIȘINĂU
}

\author{
Țîganaș Ana ${ }^{1}$, Coadă Viorica ${ }^{1}$, Zamornea Maria ${ }^{2}$, Nedbaliuc Boris ${ }^{1}$, \\ lurcu-Straistaru Elena ${ }^{1}$ \\ ${ }^{1}$ Catedra Biologia animală, Universitatea de Stat din Tiraspol, \\ ${ }^{2}$ Institutul de Zoologie, Chișinău, Republica Moldova \\ anapelin@yandex.com \\ https://doi.org/10.53937/9789975315975.64
}

Lucrarea se referă la studiul ortopterofaunei din trei sectoare ale municipiului Chișinău: sector al văii râului Ichel, pădurea parcului "Rîșcani” cu teritoriul din preajmă și bariera Sculeni cu parcul "La Izvor". În perioada anilor 2011-2018 au fost identificate 20 specii de ortoptere, ce aparţin la 16 genuri și 5 familii. În continuare, vom enumera speciile de ortoptere după, cerinţele ecologice, preferinţele trofice și răspândirea zoogeografică.

\section{FAMILIA TETTIGONIIDAE}

Decticus verrucivorus (Linnaeus, 1758). Specie mezo- xerofilă, tamnobiontă, zoofitofagă: a fost semnalată în pășuni și fâneţe cu vegetaţie ierboasă. Are o generaţie pe an, iernează în stadiul de ou. Aria de răspândire - europeană.

Tettigonia viridissima (Linnaeus, 1758). Specie zoofitofagă, monovoltină: se întâlnește în biotopuri higrofile, higro-mezofile, mezofile, mezo-xerofile și xerofile, tamnobiontă. Aria de răspândire - holarctică.

Conocephalus fuscus (Fabricius, 1793). Specie zoofitofagă, monovoltină: se întâlnește în biotopuri higrofile, higro-mezofile, mezofile, mezo-xerofile și xerofile, fitofil special. Aria de răspândire - holarctică.

Phaneroptera falcata (Poda, 1761). Specie zoofitofagă, monovoltină: se întâlnește pe ierburi înalte și tufișuri de măcieș (Rosa), lemn câinesc (Ligustrum), sânger (Cornus), în biotopuri mezofile, mezo-xerofile și xerofile, tamnobiontă. Aria de răspândire - eurosiberiană. 


\section{FAMILIA ACRIDIDAE}

Chrysocharon dispar (Germar, 1831). Specie fitofagă, monovoltină: se întâlnește în biotopuri higrofile, higro-mezofile și mezofile, fitofil special. Aria de răspândire - eurosiberiană.

Omocestus viridulus (Linnaeus, 1758). Specie fitofagă, monovoltină: se întâlnește în biotopuri higro-mezofile, mezofile și mezo-xerofile, hortobion-graminee. Arealul - eurosiberian.

Omocestus rufipes Zetterstedt, 1821). Specie fitofagă, monovoltină: se întâlnește în biotopuri însorite cu înveliș ierbos moderat - xerofile, hortobion-graminee. Arealul - european.

Chorthippus brunneus (Thunberg, 1815). Specie fitofagă, monovoltină: se întâlnește în pajiști de câmpie și deal, în biotopuri higro-mezofile, mezofile, mezo-xerofile și xerofile, hortobion-graminee. Aria de răspândire - palearctică.

Chorthippus parallelus (Zetterstedt, 1821). Specie fitofagă, monovoltină: se întâlnește în biotopuri higro-mezofile, mezofile și mezo-xerofile, hortobion-graminee. Arealul - palearctic.

Chorthippus albomarginatus (De Geer, 1773). Specie fitofagă, monovoltină: se întâlnește în biotopuri higro-mezofile, mezofile și mezo-xerofile, hortobion-graminee. Arealul - european.

Stenobothrus lineatus (Panzer, 1796). Specie fitofagă, monovoltină: se întâlnește în biotopuri mezo-xerofile și xerofile, hortobion-graminee. Arealul - mediteraneean.

Myrmeleotettix maculatus (Thunberg, 1815). Specie fitofagă, monovoltină: se întâlnește în biotopuri mezofile, mezo-xerofile și xerofile, hortobion-graminee. Arealul - european.

Paracinema tricolor bisignata (Charp., 1825). Specie fitofagă, monovoltină: se întâlnește în biotopuri higrofile și higro-mezofile, hortobion-facultativ. Arealul - mediteraneean. 


\section{FAMILIA TETRIGIDAE}

Tetrix bipunctata (Linnaeus, 1758). Specie fitofagă, monovoltină: se întâlnește în biotopuri higrofile, higro-mezofile, mezofile și mezo-xerofile, herpetobiontă. Aria de răspândire - eurosiberian.

Tetrix subulata (Linnaeus, 1758). Specie fitofagă, monovoltină: se întâlnește în biotopuri higro-mezofile, mezofile, mezo-xerofile și xerofile, herpetobiontă. Arealul - holarctic.

Depressotetrix depressa (Brisout, 1848 ). Specie fitofagă, monovoltină: se întâlnește în biotopuri higro-mezofile și mezofile, herpetobiontă. Aria de răspândire - mediteraneană.

\section{FAMILIA TRIDACTYLIDAE}

Xya variegata (Latreille, 1809). Specie fitofagă, monovoltină: se întâlnește în biotopuri higrofile, higro-mezofile, mezofile, mezo-xerofile și xerofile, geobiontă. Aria de răspândire - central-asiatic-mediteraneeană.

\section{FAMILIA GRYLLIDAE}

Gryllus campestris (Linnaeus, 1758). Specie zoofitofagă, monovoltină: se întâlnește în biotopuri higro-mezofile, mezofile, mezo-xerofile și xerofile, fisurobiontă. Aria de răspândire - holarctică.

Melanogryllus desertus (Pallas, 1771). Specie zoofitofagă, monovoltină: se întâlnește în biotopuri higro-mezofile, mezofile, mezo-xerofile și xerofile, fisurobiontă. Aria de răspândire - central-asiatic-mediteraneeană.

Oecanthus pellucens (Scopoli, 1763). Specie zoofitofagă, monovoltină: se întâlnește în biotopuri mezofile, mezo-xerofile și xerofile, fisurobiontă. Arealul - central-asiatic-mediteraneean.

Numărul speciilor de ortoptere, scade odată cu scăderea cantităţi de vegetaţie ierboasă, reducerea numărului de plante prezente și creșterea influenţelor antropice în biotopurile studiate.

Studiile au fost realizate în cadrul proiectului instituțional fundamental 15.817.02.12F. 